\title{
Evidence for a gonadal nonsteroidal factor that specifically inhibits release of luteinizing hormone in ewes
}

\author{
K. H. Al-Gubory ${ }^{1}$, J. Martinet ${ }^{1}$, M. R. Blanc ${ }^{2}$, J. C. Poirier ${ }^{2}$ and A. Solari ${ }^{1}$ \\ ${ }^{1}$ INRA, Station de Physiologie Animale, Unité d'Endocrinologie de l'Embryon, F-78352 Jouy-en- \\ Josas Cédex; and ${ }^{2}$ INRA, Station de Physiologie de la Reproduction, Laboratoire de
}

Neuroendocrinologie, F-37380 Nouzilly, France

\begin{abstract}
Summary. Bilaterally ovariectomized ewes were used to investigate the effect of systemic administration (i.v.) of charcoal-treated aqueous luteal extracts from ovine corpora lutea on plasma concentrations of pituitary gonadotrophins. Jugular blood samples were taken every $15 \mathrm{~min}$ at least $5 \mathrm{~h}$ before (control period) and $5 \mathrm{~h}$ after (treatment period) injection. In Expt 1, the administration of luteal extract from corpora lutea of days 70-76 of pregnancy, but not of the extract prepared from muscular tissue, resulted in a significant decrease of mean concentrations of luteinizing hormone ( $\mathrm{LH})(P<0.02)$ and frequency of $\mathrm{LH}$ pulses $(P<0 \cdot 01)$. Plasma follicle-stimulating hormone (FSH) concentrations were not affected by injections of either extract. These findings provide the first demonstration of the presence of a nonsteroidal factor in the corpus luteum of midpregnancy that selectively suppresses the secretion of LH. In Expt 2, mean concentrations of LH and FSH and frequency of LH pulses were unaffected by injections of luteal extracts from ovine corpora lutea of days 10-12 of the oestrous cycle or day 15 of pregnancy. These data suggest that some factor(s), probably from the fetoplacental endocrine unit, is required to ensure the production of a significant quantity of the luteal LH-inhibiting factor after day 15 of pregnancy. In Expt 3, treatment of luteal extract from corpora lutea of day 70 of pregnancy with proteolytic enzymes destroyed the LH-inhibiting activity, suggesting the proteic nature of the luteal LH-inhibiting factor. In Expt 4, plasma concentrations of $\mathrm{LH}$ were not affected by injection of charcoal-treated extract prepared from fetal cotyledonary tissue of days 110-120 of pregnancy suggesting that the LH-inhibiting factor exclusively originates from the corpus luteum during pregnancy.

These experiments provide the first direct evidence for the existence of a potent nonsteroidal factor of luteal origin that specifically inhibits pulsatile secretion of $\mathrm{LH}$, without influencing FSH release in female animals. We propose the term LH-releaseinhibiting factor (LH-RIF) to describe this activity.
\end{abstract}

Keywords: ewe; corpus luteum; luteinizing hormone; follicle-stimulating hormone; LH-releaseinhibiting factor

\section{Introduction}

During pregnancy, the maintenance of luteal function in most mammals depends on a complex relationship between the fetoplacental unit, the ovaries and the hypophysis (for review, see Denamur, 1968; Moor, 1968). One important function of the corpus luteum is the synthesis and secretion of progesterone, which is required to establish and maintain pregnancy. In some species, ovariectomy can be performed during early (sheep, macaque and man) or late (cat, guinea-pig, cow and horse) pregnancy without inducing abortion (for review, see Ryan, 1969). In these species, 
during the period when the fetoplacental endocrine unit assumes a predominant role in progesterone secretion, the physiological importance of the presence of the functional corpus luteum is unknown. In sheep, while the corpus luteum is not necessary for maintenance of pregnancy during the last two-thirds (Casida \& Warwick, 1945; Neher \& Zarrow, 1954; Denamur \& Martinet, 1955), it affects the recruitment of the primordial follicles systemically (Al-Gubory \& Martinet, 1986; Al-Gubory et al., 1987) and locally (Al-Gubory \& Martinet, 1987). It has also been demonstrated that surgical removal of the corpus luteum at day 70 of pregnancy has no subsequent effect on plasma concentrations of progesterone and follicle-stimulating hormone (FSH), but results in an increase in the frequency of pulses of luteinizing hormone (LH) release (Al-Gubory et al., 1989a). The frequency of LH pulses increases more rapidly during the early post-partum period in ewes from which the corpus luteum was removed at midpregnancy than in intact ewes (Al-Gubory et al., $1989 \mathrm{~b}$ ). These two reports provide the first evidence that the ovine corpus luteum of pregnancy produces a factor, other than progesterone, that specifically inhibits release of LH. The present experiments investigated the presence of this compound in ovine corpus luteum and its nature.

\section{Materials and Methods}

\section{Experimental animals and management}

Adult ewes of the Préalpes-du-Sud breed were bilaterally ovariectomized l-4 months before treatment. They were housed under conditions of natural daylength and temperature, fed straw and hay daily and had free access to mineral licks and water. Since the presence of rams affects the frequency of the LH pulses in ewes (Martin et al., 1983), the ewes were isolated from rams throughout the experiment.

\section{Preparation of extracts of ovine corpora lutea, placental and muscular tissue}

At midpregnancy (days 70-76), corpora lutea were surgically removed as described by Al-Gubory et al. (1989a), immediately frozen in liquid nitrogen and stored at $-20^{\circ} \mathrm{C}$ until used. Corpora lutea of early (day 15) and late (days $110-120)$ pregnancy and of the oestrous cycle (days 10-12), fetal cotyledons of days 110-120 of pregnancy and muscle were collected at the local abattoir, frozen in liquid nitrogen and stored at $-20^{\circ} \mathrm{C}$. On the day of injection of ovariectomized ewes, corpora lutea, cotyledons or muscle were thawed, minced and homogenized in ice-cold saline $\left(0.154 \mathrm{~mol} \mathrm{NaCl} 1^{-1}\right)$. The homogenate was stirred for $20 \mathrm{~min}$ and centrifuged for $30 \mathrm{~min}$ at $20000 \mathrm{~g}$. The supernatant was stirred with dextran-coated charcoal ( $5 \mathrm{mg}$ dextran and $50 \mathrm{mg}$ charcoal in $1 \mathrm{ml}$ extract) for $15 \mathrm{~min}$ and centrifuged for $30 \mathrm{~min}$ at $20000 \mathrm{~g}$. The resulting supernatant was extracted again with dextran-coated charcoal ( $1 \mathrm{mg}$ dextran and $10 \mathrm{mg}$ charcoal in $1 \mathrm{ml}$ ) for $15 \mathrm{~min}$, centrifuged as already described and then filtered through a $0.45 \mu \mathrm{m}$ Millipore filter. All operations were conducted at $4^{\circ} \mathrm{C}$. After charcoal treatments, $99 \cdot 7 \%$ of the luteal and placental progesterone had been removed.

\section{Animal treatments}

In a pilot trial (August 1987), a single i.v. injection of charcoal-treated aqueous luteal extract $(6 \mathrm{ml})$ from four corpora lutea of day 70 of pregnancy caused a decrease in plasma LH concentration for at least $5 \mathrm{~h}$, with a maximum decrease at about $4 \mathrm{~h}$ after treatment in ewes that had been ovariectomized 4 months earlier (Fig. 1). On the basis of results of this experiment, the conditions used in four other experiments were a single i.v. injection of $6 \mathrm{ml}$ luteal extract per ewe (equivalent to four corpora lutea) and blood sampling for at least $5 \mathrm{~h}$ after treatment.

In the four experiments, blood samples were taken from the jugular vein into evacuated heparinized tubes every $15 \mathrm{~min}$ for $10-12 \mathrm{~h}$ beginning at 09:00 h. Injections were given after a control bleeding period of 5-6h. Samples were kept at $4^{\circ} \mathrm{C}$ before centrifugation $\left(3000 \mathrm{~g}\right.$ ) for $30 \mathrm{~min}$. Plasma was stored at $-20^{\circ} \mathrm{C}$ until the hormone concentrations were assayed.

Experiment 1. This experiment examined the effect of administration of aqueous extracts from corpora lutea of days 70-76 of pregnancy on the secretion of LH and FSH in ten ewes. At day 30 after ovariectomy (8 April 1988), blood samples were taken from each ewe every $15 \mathrm{~min}$ for $11 \mathrm{~h}$ beginning at 09:00 h. At day 40 after ovariectomy (18 April), five ewes received luteal tissue extract and the other five ewes were injected with 6 ml muscular tissue extract (equivalent to the weight of four corpora lutea).

Experiment 2. This experiment investigated the effect of administration of aqueous extracts from cyclic (days $10-12$ ) or early pregnancy (day 15) corpora lutea on the secretion of LH and FSH, in the ten ovariectomized ewes used in Expt 1. At day 70 after ovariectomy (18 May), ewes were sampled for $11 \mathrm{~h}$ and given extracts of cyclic $(n=3)$, early 


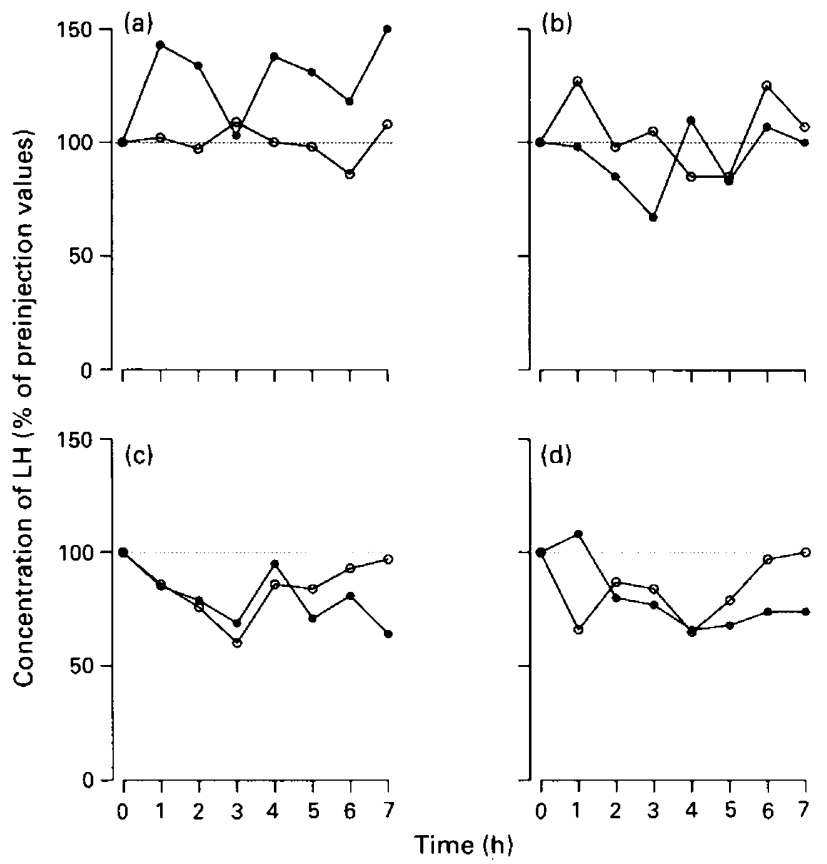

Fig. 1 Effects of i.v. injection of $6 \mathrm{ml}$ saline $(0.9 \% \mathrm{NaCl})$ (a) charcoal-treated aqueous luteal extracts $(6 \mathrm{ml})$ from one (b), two (c) or four (d) corpora lutea of day 70 of pregnancy, on plasma concentrations of luteinizing hormone $(\mathrm{LH})$ in eight ovariectomized ewes (two ewes per group). Data are expressed as percentage of control $(0 \mathrm{~h})$ and each line refers to an individual ewe.

pregnancy $(n=2)$ corpora lutea or extracts of muscular tissue $(n=5)$. Eight days later (day 78 after ovariectomy), the five ewes that received luteal tissue extracts were treated with muscular tissue extracts, whereas the five ewes that received the muscular extracts were treated with luteal extract from cyclic $(n=3)$ or early pregnancy $(n=2)$ corpora lutea.

Experiment 3. This experiment tested the effect of administration of protease-treated extract from corpora lutea of midpregnancy on LH secretion in four ovariectomized ewes. Before the injection, charcoal-treated extract from corpora lutea of day 70 of pregnancy was incubated at $37^{\circ} \mathrm{C}$ for $3 \mathrm{~h}$ with proteinase $\mathrm{K}\left(200 \mu \mathrm{g} \mathrm{ml}^{-1}\right)$ and then for $3 \mathrm{~h}$ with pronase $\left(200 \mu \mathrm{g} \mathrm{ml}^{-1}\right)$. At day 40 after ovariectomy (29 November 1989), each ewe received $6 \mathrm{ml}$ of this extract.

Experiment 4. The effect of aqueous extracts from corpora lutea or fetal cotyledons of days 110-120 of pregnancy on LH secretion was investigated. At day 35 after ovariectomy (November 1990), five ewes received luteal tissue extract and the other five ewes were injected with cotyledonary tissue extract.

\section{Assay of LH and FSH}

All samples from the same experiment were run in duplicate and assayed separately for each hormone. Plasma concentrations of LH were measured by a double-antibody radioimmunoassay as described by Pelletier $e t$ al. (1982) using NIH-LH-S1 as standard. The intra-assay coefficient of variation was $<6 \%$ and the limit of sensitivity was $0.2 \mathrm{ng} \mathrm{ml}^{-1}$. FSH concentrations were measured by the double-antibody radioimmunoassay of Blanc \& Poirier (1979) with NIH-FSH-S3 as standard. The intra-assay coefficient of variation was $<3 \%$ and the limit of sensitivity was $2 \mathrm{ng}$ $\mathrm{ml}^{-1}$.

\section{Data analysis}

The PUlSAR ALGORITHMIC PROGRAM developed by Merriam \& Wachter (1982) for the study of pulsatile hormone secretion was used to calculate the basal concentrations, the frequency and the amplitude of gonadotrophin episodic release (pulses) in individual profiles of the serial sampling period. The $G$ values, or number of assay coefficients of 
variation by which a pulse must exceed the base line, were $3.00,2 \cdot 26,1 \cdot 56,1.50$ and 1.20 for pulses with one to five consecutive increased points, respectively. Samples collected before injection were considered as the control period for each ewe. The effects of injection within each group were assessed using the general linear models (GLM) procedures of the statistical analysis system (SAS, 1987) for repeated measures.

\section{Results}

\section{Experiment 1}

The $11 \mathrm{~h}$ profiles $(09: 00-20: 00 \mathrm{~h})$ of $\mathrm{LH}$ and FSH in four representative ovariectomized ewes (Fig. 2) show that, as expected, plasma concentrations of LH fluctuated in an episodic manner. During the sampling period, 11.4 LH pulses (range 9-13) were identified, which occurred every $45 \mathrm{~min}$ (range 30-75 min). During this period, neither LH pulse frequency nor FSH concentrations changed with hour of sampling.

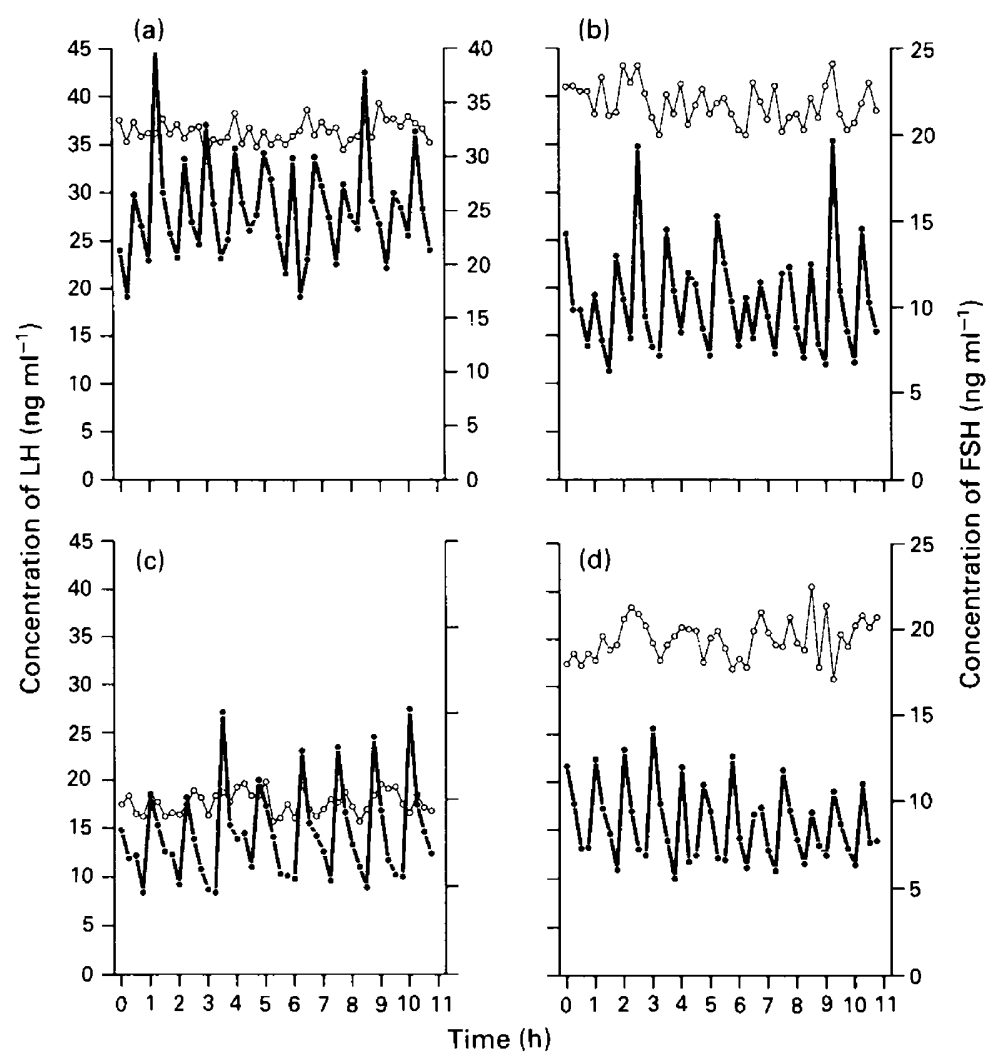

Fig. 2. Concentrations of luteinizing hormone ( $\mathrm{LH}, 0)$ and follicle-stimulating hormone (FSH, $O$ ) in plasma samples collected from the jugular vein for $15 \mathrm{~min}$ over an 11 -h sampling period in four ovariectomized ewes. Note scale of FSH in (a).

Peripheral concentrations of LH were markedly reduced after injection of charcoal-treated extracts from corpora lutea of days 70-76 of pregnancy, but not from muscular tissue (Fig. 3). Luteal extracts significantly $(P<0.02)$ lowered mean LH concentrations from $17.3 \pm 2.6$ to $12.2 \pm 1.3 \mathrm{ng} \mathrm{ml}^{-1}$. The frequency of LH pulses was significantly $(P<0.01)$ different before and after treatment $(5.8 \pm 0.2$ versus $2.2 \pm 0.6$ per $5.5 \mathrm{~h})$, but the amplitude of $\mathrm{LH}$ pulses before 


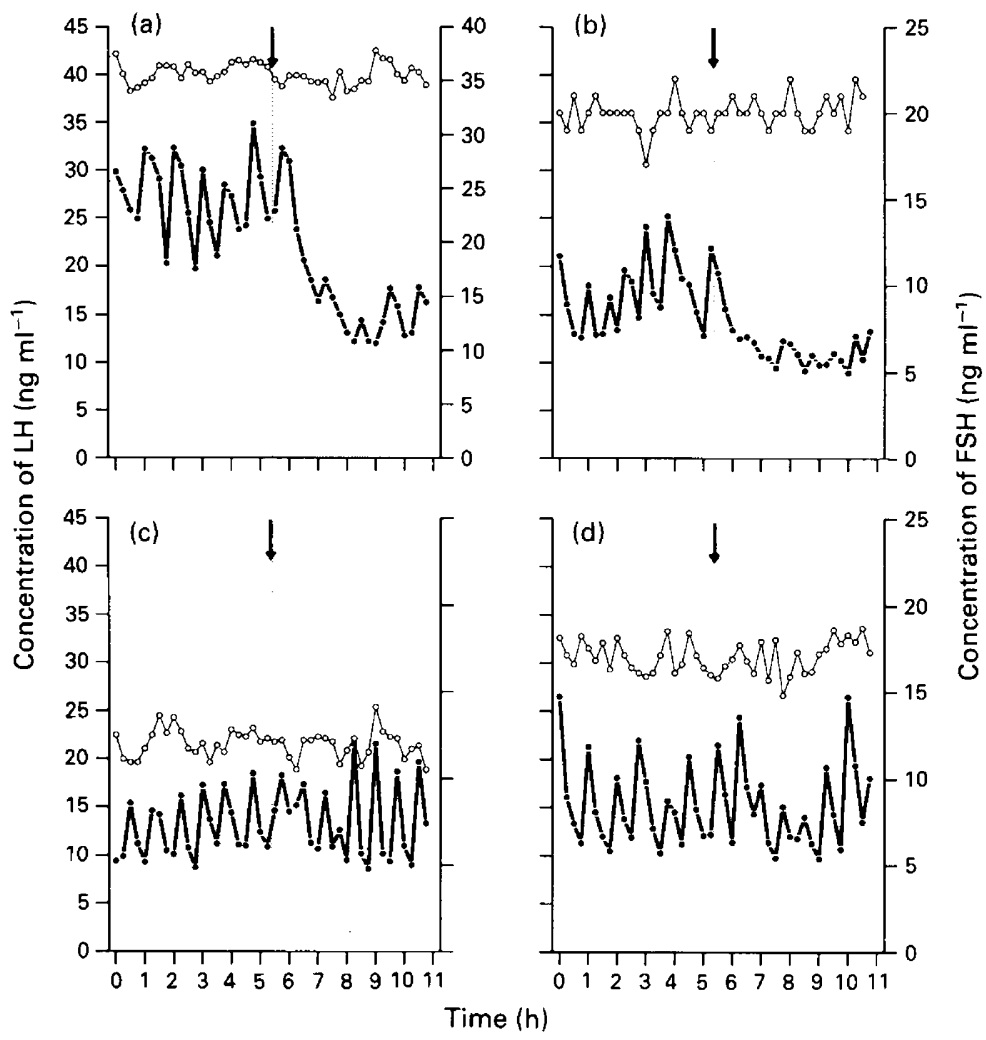

Fig. 3. Concentrations of luteinizing hormone ( $\mathrm{LH}, 0)$ and follicle-stimulating hormone (FSH, O) in plasma samples collected from the jugular vein for $15 \mathrm{~min}$ over an 11-h sampling period in four ovariectomized ewes injected (i.v.) with charcoal-treated luteal tissue extract from corpora lutea of days $70-76$ of pregnancy ( $a$ and $b$ ), or charcoal-treated muscular tissue extract (c and d). Time of injection is indicated by the arrow. Note scale of FSH in (a).

$\left(7.6 \pm 0.6 \mathrm{ng} \mathrm{ml}^{-1}\right)$ and after $\left(7.1 \pm 1.3 \mathrm{ng} \mathrm{ml}^{-1}\right)$ treatment with luteal extract was not signifcantly different. Plasma FSH concentrations were not affected by injections of luteal or muscular tissue extracts (Fig. 3).

\section{Experiment 2}

Injection of luteal tissue extracts from corpora lutea of days 10-12 of the oestrous cycle or day 15 of pregnancy did not produce changes in pulsatile LH release, nor did muscular tissue extract (Fig. 4), except in one of the four ewes treated with extract from corpora lutea of day 15 of pregnancy (Fig. 4e). The mean plasma LH concentrations before and after injection of luteal tissue extracts of days 10-12 of the oestrous cycle $\left(17.2 \pm 1.1\right.$ versus $\left.17.9 \pm 1.2 \mathrm{ng} \mathrm{ml}^{-1}\right)$ or day 15 of pregnancy $\left(18.8 \pm 2.7\right.$ versus $\left.17.9 \pm 2.1 \mathrm{ng} \mathrm{ml}^{-1}\right)$ and muscular tissue extract $(18.3 \pm 1.6$ versus $17.6 \pm 1.4 \mathrm{ng} \mathrm{ml}^{-1}$ ) were not significantly different. Plasma concentrations of FSH were not affected by any of the above treatments (Fig. 4).

\section{Experiment 3}

Peripheral concentration of LH was not affected after injection of protease-treated extracts from corpora lutea of day 70 of pregnancy (Fig. 5). No differences were found between the 

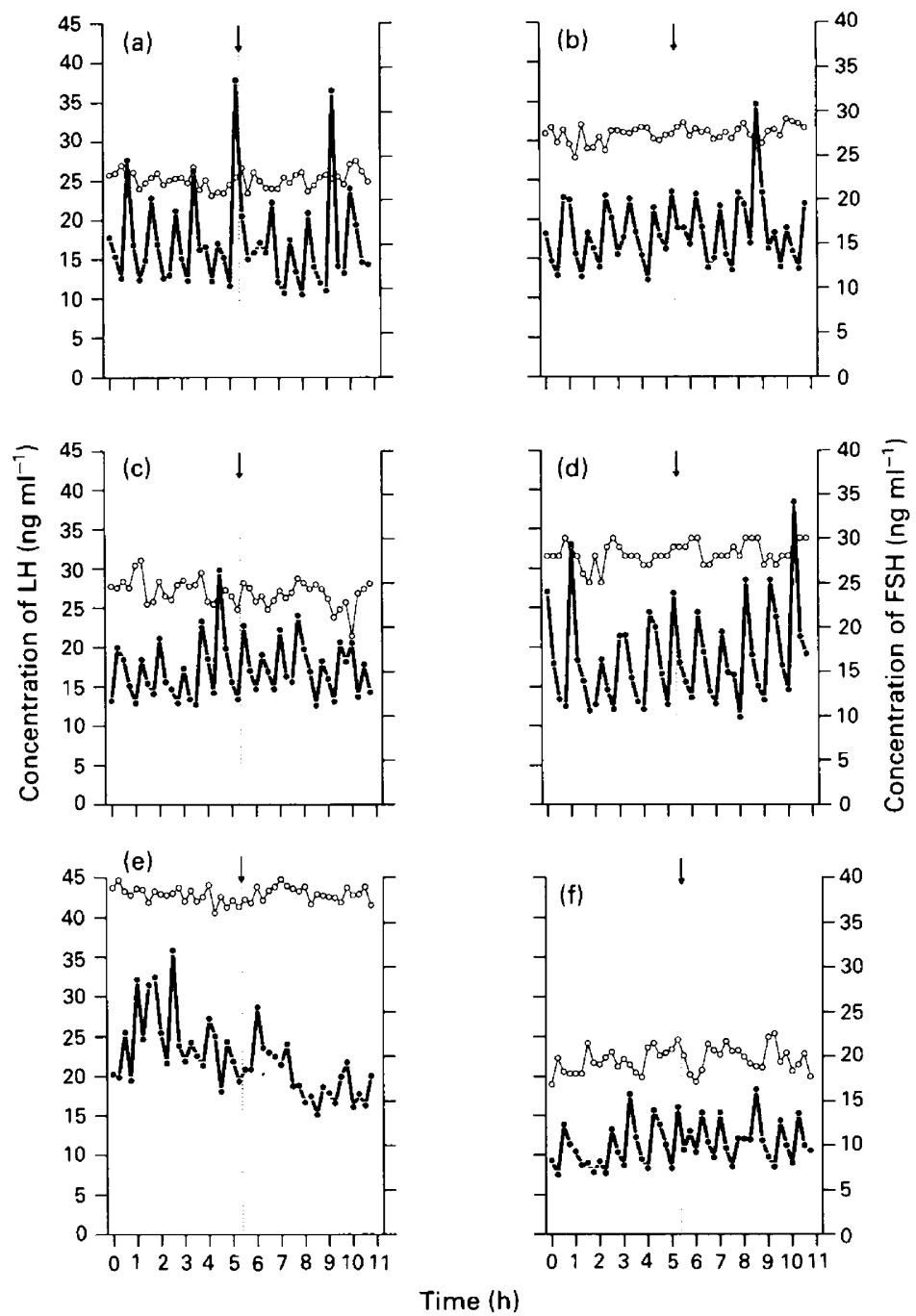

Fig. 4. Concentrations of luteinizing hormone ( $\mathrm{LH}, 0)$ and follicle-stimulating hormone (FSH, O) plasma samples collected from the jugular vein for 15 min over an 11 -h sampling period in individual ovariectomized ewes injected (i.v.) with charcoal-treated muscular tissue extract (a and $b$ ), charcoal-treated luteal tissue extracts from corpora lutea of days 10-12 of the oestrous cycle ( $\mathrm{c}$ and $\mathrm{d}$ ), or day 15 of pregnancy ( $\mathrm{e}$ and $\mathrm{f}$ ). Time of injection is indicated by the arrow.

pre-treatment and the post-treatment periods in the frequency $(6.5 \pm 0.6$ versus $6.0 \pm 0.6$ per $6 \mathrm{~h})$ or the amplitude $\left(3.9 \pm 1.0\right.$ versus $\left.3.2 \pm 0.6 \mathrm{ng} \mathrm{ml}^{-1}\right)$ of $\mathrm{LH}$ pulses.

\section{Experiment 4}

There was great variability in the $\mathrm{LH}$ response among ewes treated with extracts from corpora lutea of days 110-120 of pregnancy (Fig. 6). Two of the five ewes showed a response to this treatment (Fig. 6a,c). No significant differences were found before and after treatment in the frequency $(5.8 \pm 0.8$ versus $5.8 \pm 0.9$ per $5 \mathrm{~h})$ or the amplitude $(3.7 \pm 0.7$ versus $2.9 \pm 0.5 \mathrm{ng}$ $\mathrm{ml}^{-1}$ ) of LH pulses. Pulsatile LH release was not affected in ewes that received extracts from fetal cotyledons of days $110-120$ of pregnancy (Fig. $6 \mathrm{~b}, \mathrm{~d}, \mathrm{f}$ ). 


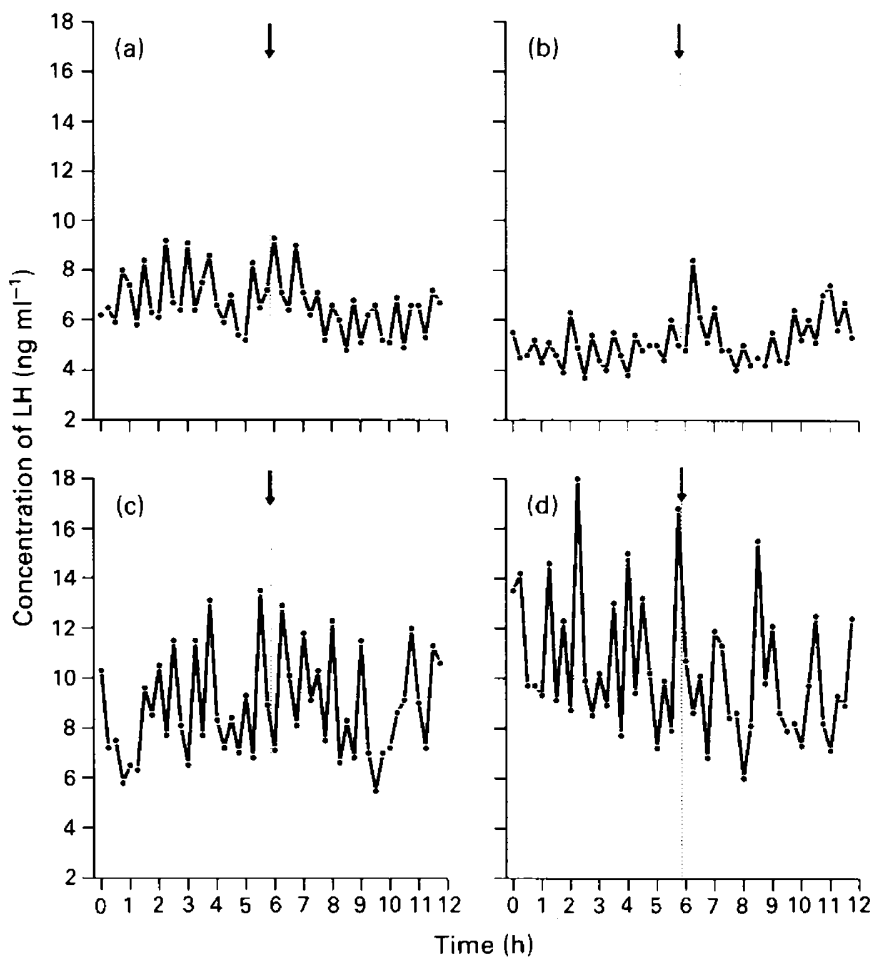

Fig. 5. Concentrations of luteinizing hormone (LH) in plasma samples collected from the jugular vein for $15 \mathrm{~min}$ over a 10 -h sampling period in individual ovariectomized ewes injected (i.v.) with protease-treated luteal extract from corpora lutea of day 70 of pregnancy. Time of injection is indicated by the arrow.

\section{Discussion}

In ewes, plasma concentrations of LH and frequency and amplitude of LH pulses were low and relatively stable between days 60 and 140 of pregnancy (Al-Gubory et al., 1989a, b) and increased markedly after surgical removal of the corpora lutea at day 70 of pregnancy (Al-Gubory et al., 1989a). Under these experimental conditions, peripheral concentrations of FSH were not affected. Since the ovine placenta is the main source of progesterone during the last two-thirds of pregnancy (Linzell \& Heap, 1968; Moore et al., 1972), plasma concentrations of this steroid are not markedly affected after bilateral ovariectomy (Beal et al., 1986) or corpus luteum excision (Al-Gubory et al., 1989a) performed at midpregnancy. Pulsatile LH release increased more rapidly after parturition in ewes from which corpora lutea were removed at day 70 of pregnancy than in intact ewes, whereas peripheral concentrations of progesterone could not be detected during the first 20 days post partum in either group of ewes (Al-Gubory et al., 1989b). Our findings (Al-Gubory et al., 1989a, b) constitute the first demonstration that the corpus luteum of pregnancy secretes a factor, other than progesterone, that contributes selectively to the inhibition of pulsatile LH secretion. The results of the present experiments confirm these observations and provide a clear demonstration of the presence of a nonsteroidal factor in the ovine corpus luteum of pregnancy. The degree of inhibition of luteal extract from corpora lutea of day 15 (Expt 2), days 70-76 (Expt 1) or days 110-120 (Expt 4) of pregnancy on the secretion of LH was widely different (i.e. $1 / 4,5 / 5,2 / 5$ ewes, respectively, showed a clear response). These results could be of significant physiological value and may reflect differences in luteal content of the LH-inhibiting factor. However, this interpretation is still far from complete and needs additional investigation. Nevertheless, compared with luteal extract from 

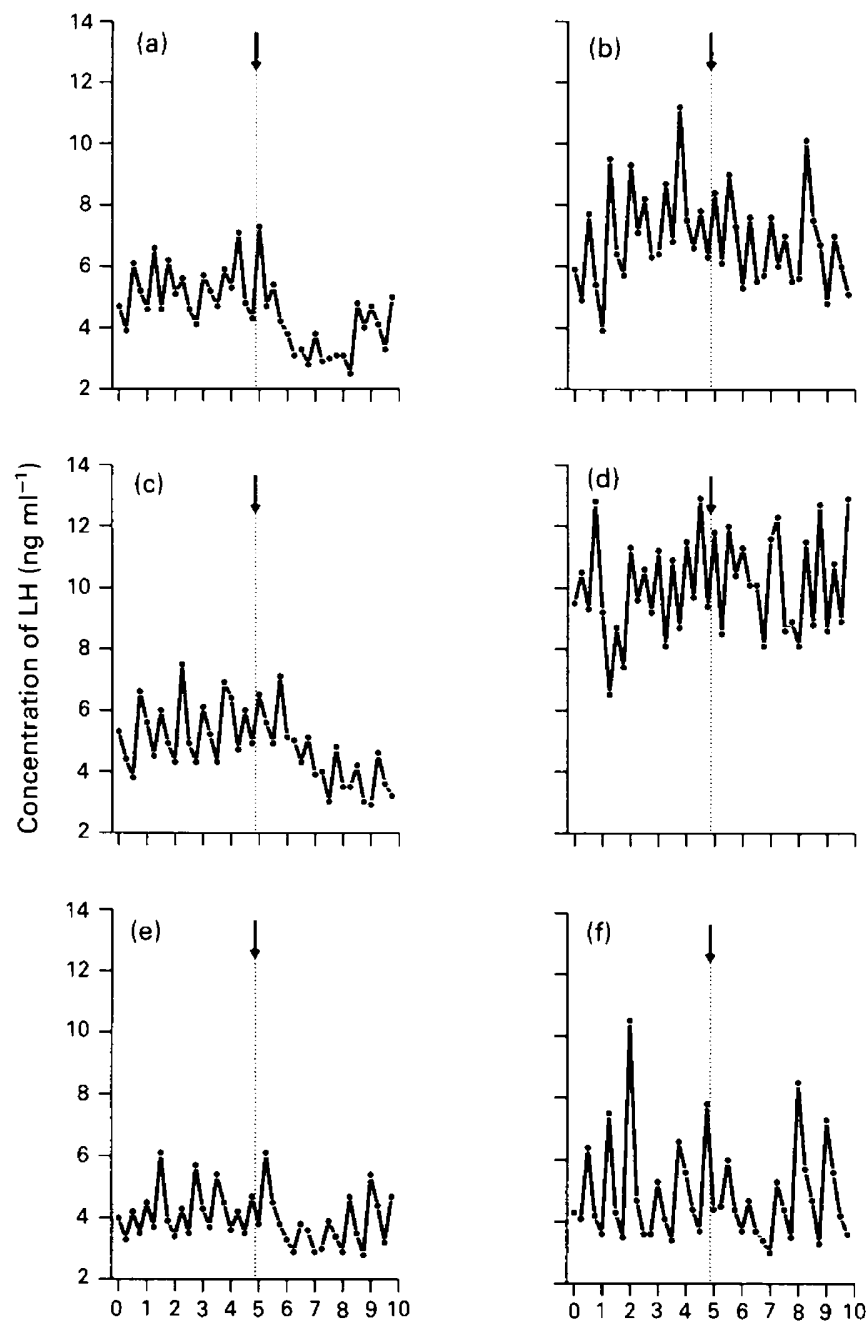

Time $(\mathrm{h})$

Fig. 6. Concentrations of luteinizing hormone (LH) in plasma samples collected from the jugular vein for $15 \mathrm{~min}$ over a 10 -h sampling period in individual ovariectomized ewes injected (i.v.) with charcoal-treated extracts of corpora lutea (a, c and e), or fetal cotyledons (b, $d$ and $f$ ) of days 110-120 of pregnancy. Time of injection is indicated by the arrow.

corpora lutea of days 110-120, the failure of injection of extract from placental tissue of the same stage of pregnancy to affect the secretion of $\mathrm{LH}$ in any of the five treated ewes could be taken as an argument in favour of the hypothesis that the LH-inhibiting factor is exclusively of luteal origin. Mean concentrations of $\mathrm{LH}$ and frequency of $\mathrm{LH}$ pulses were unaffected in ewes that received luteal extracts from corpora lutea of days 10-12 of the oestrous cycle (Expt 2). These findings suggest that some message, still unknown, is required for the production of large quantities of the luteal LH-inhibiting factor and is probably delivered from the fetoplacental unit. Treatment of luteal extracts from corpora lutea of day 70 of pregnancy with proteolytic enzymes (proteinase $\mathrm{K}$ and pronase) destroyed the luteal $\mathrm{LH}$-inhibiting activity. It appears, therefore, that the luteal LH-inhibiting factor is proteic in nature.

There is now considerable experimental evidence that ovarian follicular fluid from various species, including sheep, contains several nonsteroidal factors, in particular inhibin, follistatin and 
activin, that selectively affect the synthesis and secretion of FSH (for review see Ying, 1988; De Krester \& Robertson, 1989) by direct action on the pituitary gland (Carroll et al., 1989). In ovariectomized ewes, various studies have shown that only supraphysiological doses of ovine or bovine follicular fluid administered 2-3 times day ${ }^{-1}$ for at least 2-3 days can reduce plasma LH concentrations (Cummins et al., 1983; Findlay et al., 1985; Clarke et al., 1986; Martin et al., 1986, 1987, 1988; McNatty et al., 1989) suggesting that inhibin or other follicular fluid proteins may play a role in the control of secretion of LH. However, Knight \& Castillo (1988) failed to show any effect of high doses of follicular fluid on spontaneous LH release or induced by exogenous gonadotrophinreleasing hormone in ovariectomized ewes. It has also been demonstrated, by using frequent portal and jugular blood sampling schedules, that administration of follicular fluid into ovariectomized ewes had no effect on pulsatile release of LH (Knight \& Castillo, 1988; Li et al., 1989) and gonadotrophin-releasing hormone (Li et al., 1989). Since peripheral injection of highly purified inhibin selectively suppressed plasma FSH concentrations, without affecting plasma concentrations of LH in ovariectomized rats (Ying et al., 1987), ewes (Findlay et al., 1987) and heifers (Beard et al., 1990), it would appear unlikely that inhibin contributes to the regulation of LH secretion. These results are in agreement with those reported by Lumpkin et al. (1981), who showed that injection of purified inhibin preparation into the third ventricle of conscious orchidectomized rats specifically depressed plasma FSH concentrations, within $4 \mathrm{~h}$ of injection, with no effect on LH release. Under our experimental conditions, a single i.v. injection of charcoal-treated extract from corpora lutea of midpregnancy selectively suppressed pulsatile LH release, without influencing FSH secretion in ovariectomized ewes. These results therefore suggest that the factor (LHinhibiting factor) in the corpus luteum of pregnancy is distinct from inhibin, at least in terms of its biological activity.

There is considerable evidence that follicular oestradiol is directly involved in the luteolytic process in ewes (Stormshak et al., 1969; Hawk \& Bolt, 1970; Karsch et al., 1970; Ginther, 1971; Howland et al., 1971; Denamur \& Kann, 1973; Barcikowski et al., 1974). The role of oestradiol in luteolysis appears to be via the induction of uterine oxytocin receptors (McCracken et al., 1984; Hixon \& Flint, 1987) and oxytocin then stimulates the secretion of the uterine prostaglandin $\mathrm{F}_{2 \alpha}$ (Fairclough et al., 1984; Sheldrick \& Flint, 1986). During follicular development, thecal cells respond to LH stimulation leading to production of androstenedione, which is then converted to oestrogen by granulosa cells (for review, see Ireland, 1987). It has been demonstrated that the increased follicular androstenedione and oestradiol secretion is due to repeated stimulation by episodic LH release at the time of luteal regression (Baird et al., 1981; Campbell et al., 1990a, b). The suppression of pulsatile LH release could be one pathway that leads to the maintenance of corpus luteum activity. It is thus quite likely that the physiological significance of secretion of the luteal LH-inhibiting factor lies in the control of episodic LH release and successful maintenance of pregnancy.

The present report provides the first experimental evidence for the existence of a gonadal protein that selectively inhibits the secretion of $\mathrm{LH}$, but not of FSH, in female animals. The term LH-release-inhibiting factor (LH-RIF) is proposed to describe this activity, which is distinct from that of highly purified inhibin (Findlay et al., 1987; Ying et al., 1987; Beard et al., 1990) and recombinant inhibin (Rivier et al., 1991), which specifically suppresses FSH secretion without affecting $\mathrm{LH}$ release.

The authors are most grateful to J. Martal, Director of the Animal Physiology Laboratory (APL), INRA Jouy-en-Josas, for the use of facilities, H. Clauser, C. Thibault and P. Gaye for valuable comments; M. E. Marmillod for typing the manuscript and N. Neimer for figures. We should like to thank the staff of the APL for helping with blood sampling and maintenance of the animals. K. H. Al-Gubory is grateful to P. Mauléon, Head-counsel of the Director of the National Institute of the Agronomic Research, for his encouragement and interest in the study. 


\section{References}

Al-Gubory, K.H. \& Martinet, J. (1986) Comparison of the total ovarian follicular populations at day 140 of pregnancy and at day 5 postpartum in ewes. Theriogenology 25, 795-808.

Al-Gubory, K.H. \& Martinet, J. (1987) Effect of the corpus luteum on ovarian follicular populations and growth in the ewe. Animal Reproduction Science 13, 269-281.

Al-Gubory, K.H., Martinet, J., Paly, J. \& Solari, A. (1987) A new concept for control of folliculogenesis during pregnancy in ewes: role of the corpus luteum. Animal Reproduction Science 15, 113-120.

Al-Gubory, K.H., Blanc, M.R., Poirier, J.C., Solari, A. \& Martinet, J. (1989a) Evidence that the corpus luteum of pregnancy contributes to the control of tonic secretion of LH in the ewe. Journal of Reproduction and Fertility 85, 125-131.

Al-Gubory K.H., Blanc, M.R. \& Martinet, J. (1989b) Role of the corpus luteum of pregnancy in controlling pituitary gonadotrophin secretion during the early post-partum period in the ewe. Journal of Reproduction and Fertility 86, 697-703.

Baird, D.T., Swanston, I.A. \& McNeilly, A.S. (1981) Relationship between LH, FSH and prolactin concentration and the secretion of androgens and estrogens by the pre-ovulatory follicle in the ewe. Biology of Reproduction 24, 1013-1025.

Barcikowski B., Carlson, J.C., Wilson, L. \& McCracken, J.A. (1974) The effect of endogenous and exogenous estradiol-17 $\beta$ on the release of prostaglandin $F_{2 \alpha}$ from the ovine uterus. Endocrinology 95, 1340-1349.

Beal, W.T., Orthank, D.C. \& Zirkle, S.M. (1986) Effects of human chorionic gonadotropin and cyclic adenosine monophosphate on progesterone secretion by the ovine placenta. Journal of Animal Science 63, $184-188$.

Beard, A.J., Castillo, R.J., McLeod, B.J., Glencross, R.G. \& Knight, P.G. (1990) Comparison of the effects of crude and highly purified bovine inhibin $\left(M_{\mathrm{r}}\right.$ 32000 ) on plasma concentrations of FSH and $\mathbf{L H}$ in chronically ovariectomized prepubertal heifers. Journal of Endocrinology 125, 21-30.

Blanc, M.R. \& Poirier, J.C. (1979) A new homologous radioimmunoassay for ovine follicle stimulating hormone: development and characterization. Annales de Biologie animale, Biochimie et Biophysique 19, $101 \mathrm{l}-1026$

Campbell, B.K., Mann, G.E., McNeilly, A.S. \& Baird, D.T. (1990a) Pulsatile secretion of inhibin, oestradiol and androstenedione by the ovary of the sheep during the oestrous cycle. Journal of Endocrinology 126, 385-393.

Camphell, B.K., McNeilly, A.S., Picton, H.M. \& Baird, D.T. (1990b) The effect of a potent gonadotrophinreleasing hormone antagonist on ovarian secretion of oestradiol, inhibin and androstenedione and the concentration of LH and FSH during the follicular phase of the sheep oestrous cycle. Journal of Endocrinology 126, 377-384.

Carroll, R.S., Corrigan, A.Z., Gharib, S.D., Vale, W. \& Chin, W.W. (1989) Inhibin, activin, and follistatin: regulation of follicle-stimulating hormone messenger ribonucleic acid levels. Molecular Endocrinology 3, 1969-1976.

Casida, L.E. \& Warwick, E.J. (1945) The necessity of the corpus luteum for maintenance of pregnancy in the ewe. Journal of Animal Science 4, 34-36.

Clarke, I.J., Findlay, J.K., Cummins, J.T. \& Ewens, W.J. (1986) Effects of ovine follicular fluid on plasma $\mathbf{L H}$ and FSH secretion in ovariectomized ewes to indicate the site of action of inhibin. Journal of Reproduction and Fertility 77, 575-585.

Cummins, L.T., O'Shea, T., Bindon, B.M., Lee, N.W. \& Findlay, J.K. (1983) Ovarian inhibin content and sensitivity to inhibin in Booroola and control strain Merino ewes. Journal of Reproduction and Fertility 67, 1-7.

De Kretser, D.M. \& Robertson, D.M. (1989) The isolation and physiology of inhibin and related proteins. Biology of Reproduction 40, 33-47.

Denamur, R. (1968) Formation and maintenance of corpora lutea in domestic animals. Journal of Animal Science 27, Supplement 1, 163-180.

Denamur, R. \& Kann, G. (1973) Luteolytic effects of oestradiol after hypophysectomy or pituitary stalk section in cycling sheep. Acta Endocrinologica, Copenhagen 73, 635-642.

Denamur, R. \& Martinet, J. (1955) Effets de l'ovariectomie chez la brebis pendant la gestation. Comptesrendus hebdomadaires des Séances de l'Académie des Sciences, Paris D 149, 2105-2107.

Fairclough, R.J., Moore, L.G., Peterson, A.J. \& Watkins W.B. (1984) Effect of oxytocin on plasma concentrations of 13,14-dihydro-15-keto prostaglandin $F$ and the oxytocin-associated neurophysin during the estrous cycle and early pregnancy in the ewe. Biology of Reproduction 31, 36-43.

Findlay, J.K., Gill, T.W. \& Doughton, B.W. (1985) Influence of season and sex on the inhibitory effect of ovine follicular fluid on plasma gonadotrophins in gonadectomized sheep. Journal of Reproduction and Fertility 73, 329-335.

Findlay, J.K., Robertson, D.M. \& Clarke, I.J. (1987) Influence of dose and route of administration of bovine follicular fluid and the suppressive effect of purified bovine inhibin $\left(M_{\mathrm{r}} 31000\right)$ on plasma FSH concentrations in ovariectomized ewes. Journal of Reproduction and Fertility 80, 455-461.

Ginther, O.J. (1971) Response of corpora lutea to cauterization of follicles in sheep. American Journal of Veterinary Research 32, 59-62.

Hawk, H.W. \& Bolt, D.J. (1970) Luteolytic effect of oestradiol-17 $\beta$ when administered after midcycle in the ewe. Biology of Reproduction 2, 275-278.

Hixon, J.E. \& Flint, A.P.F. (1987) Effects of a luteolytic dose of estradiol benzoate on uterine oxytocin receptor concentrations, phosphoinositide turnover and prostaglandin $F_{2 a}$ secretion in sheep. Journal of Reproduction and Fertility 79, 457-467.

Howland, B.E., Akbar, A.M. \& Stormshak, F. (1971) Serum LH levels and luteal weight in ewes following a single injection of estradiol. Biology of Reproduction 5, 25-29. 
Ireland, J.J. (1987) Control of follicular growth and development. Journal of Reproduction and Fertility Supplement 34, 39-54.

Karsch, F.J., Noveroske, J.W., Roche, J.F., Norton, H.W. \& Nalbandov, A.V. (1970) Maintenance of ovine corpora lutea in the absence of ovarian follicle. Endocrinology 87, 1228-1236.

Knight, P.G. \& Castillo, R.J. (1988) Effects of bovine follicular fluid on gonadotrophin secretion in intact and chronically ovariectomized ewes before and after desensitization of pituitary gonadotrophs to gonadotrophin-releasing hormone. Journal of Endocrinology 117, 431-439.

Li, J.Y., Francis, H. \& Clarke, I.J. (1989) Effects of bovine follicular fluid on pulsatile secretion of gonadotrophin-releasing hormone and gonadotrophins in ovariectomized ewes. Journal of Neuroendocrinology 1, 61-64.

Linzell, J.L. \& Heap, R.B. (1968) A comparison of progesterone metabolism in the pregnant sheep and goat: sources of production and an estimation of uptake by some target organs. Journal of Endocrinology 41, 433-438.

Lumpkin, M., Negro-Vilar, A., Franchimont, P. \& McCann, S. (1981) Evidence for a hypothalamic site of action of inhibin to suppress FSH release. Endocrinology 108, 1101-1104.

McCracken, J.A., Schramm, W. \& Okulicz, W.C. (1984) Hormone receptor control of pulsatile secretion of $\mathrm{PGF}_{2 \alpha}$ from the ovine uterus during luteolysis and its abrogation in early pregnancy. Animal Reproduction Science 7, 31-55.

McNatty, K.P., Hudson, N.L., Collins, F., Fisher, M., Heath, D.A. \& Henderson, K.M. (1989) Effects of oestradiol-17ß, progesterone or bovine follicular fluid on the plasma concentrations of FSH and $\mathrm{LH}$ in ovariectomized Booroola ewes which were homozygous carriers or non-carriers of a fecundity gene. Journal of Reproduction and Fertility 87, 573-585.

Martin, G.B., Scaramuzzi, R.J. \& Lindsay, D.R. (1983) Effect of the introduction of rams during the anoestrous season on the pulsatile secretion of $\mathrm{LH}$ in ovariectomized ewes. Journal of Reproduction and Fertility 67, 47-55.

Martin, G.B., Wallace, J.M., Taylor, P.L., Fraser, H.M., Tsonis, C.G. \& McNeilly, A.S. (1986) The roles of inhibin and gonadotrophin-reteasing hormone in the control of gonadotrophin secretion in the ewe. Journal of Endocrinology 111, 287-296.

Martin, G.B., Taylor, P.L. \& McNeilly, A.S. (1987) Effect of small doses of bovine follicular fluid on the tonic secretion of gonadotrophins in the ewe. Journal of Endocrinology 114, 73-79.
Martin, G.B., Price, C.A., Thiéry, J.C. \& Webb, R. (1988) Interactions between inhibin, oestradiol and progesterone in the control of gonadotrophin secretion in the ewe. Journal of Reproduction and Fertility 82, 319-328.

Merriam, G.R. \& Wachter, K.W. (1982) Algorithms for the study of episodic hormone secretion. American Journal of Physiology 243, E310-E318.

Moor, R.M. (1968) Effect of embryo on corpus luteum function. Journal of Animal Science 27 (Supplement 1), 97-118.

Moore, N.W., Barrett, S. \& Brown, J.B. (1972) Progesterone concentration in maternal and foetal blood plasma of ewes. Journal of Endocrinology 53, 187-194.

Neher, G.M. \& Zarrow, M.X. (1954) Concentration of progestin in the serum of the non-pregnant, pregnant and post-partum ewe. Journal of Endocrinology 11, 323-330.

Pelletier, J., Garnier, D.H., de Reviers, M.M., Terqui, M. \& Ortavant, R. (1982) Seasonal variation in LH and testosterone release in rams of two breeds. Journal of Reproduction and Fertility 64, 341-346.

Rivier, C., Schwall, R., Mason, A., Burton, L., Vaughan, J. \& Vale, W. (1991) Effect of recombinant inhibin on luteinizing hormone and follicle-stimulating hormone secretion in the rat. Endocrinology 128, 1548-1554.

Ryan, K.J. (1969) Theoretical basis for endocrine control of gestation. A comparative approach. In Proceedings of the International Symposium, Milan (Italy, 1968), pp. 120-131. Eds A. Pécile \& C. Finzi. Excerpta Medica Foundation, Amsterdam.

Sheldrick, E.L. \& Flint, A.P.F. (1986) Transient uterine refractoriness after oxytocin administration in ewes. Journal of Reproduction and Fertility 77, 523-529.

Statistical Analysis System, SAS Institute Inc. (1987) SAS/STAT Guide for Personal Computers, version 6. SAS, Cary, USA.

Stormshak, F., Kelley, H.E. \& Hawk, H.W. (1969) Suppression of ovine luteal function by $17 \beta$-oestradiol. Journal of Animal Science 29, 476-478.

Ying, S.Y. (1988) Inhibins, activins, and follistatins: gonadal proteins modulating the secretion of folliclestimulating hormone. Endocrine Reviews 9, 267-293.

Ying, S.Y., Czvik, J., Becker, A., Ling, N., Ueno, N. \& Guillemin, R. (1987) Secretion of follicle-stimulating hormone and production of inhibin are reciprocally related. Proceedings of the National Academy of Science, USA 84, 4631-4635.

Received 14 August 1992 